University of Nebraska - Lincoln

DigitalCommons@University of Nebraska - Lincoln

Agronomy \& Horticulture -- Faculty Publications

Agronomy and Horticulture Department

2008

Harvester Ant Nests Improve Recovery Performance of Drought Impacted Vegetation in Grazing Regimes of Semiarid Savanna, Texas

Nancy Nicolai

Texas A\&M University, College Station

Fred Smeins

Texas A\&M University, College Station

Jerry Cook

Sam Houston State University, Huntsville, Texas

Follow this and additional works at: https://digitalcommons.unl.edu/agronomyfacpub

Part of the Plant Sciences Commons

Nicolai, Nancy; Smeins, Fred; and Cook, Jerry, "Harvester Ant Nests Improve Recovery Performance of Drought Impacted Vegetation in Grazing Regimes of Semiarid Savanna, Texas" (2008). Agronomy \& Horticulture -- Faculty Publications. 201.

https://digitalcommons.unl.edu/agronomyfacpub/201

This Article is brought to you for free and open access by the Agronomy and Horticulture Department at DigitalCommons@University of Nebraska - Lincoln. It has been accepted for inclusion in Agronomy \& Horticulture -Faculty Publications by an authorized administrator of DigitalCommons@University of Nebraska - Lincoln. 


\title{
Harvester Ant Nests Improve Recovery Performance of Drought Impacted Vegetation in Grazing Regimes of Semiarid Savanna, Texas
}

\author{
NANCY NICOLAI ${ }^{1}$ AND FRED E. SMEINS \\ Department of Rangeland Ecology and Management, Animal Industries Building, MS-2126, \\ Texas AE्FM University, College Station 77843
}

AND

JERRY L. COOK

Department of Biological Sciences, 300 Lee Drain, Box 2116, Sam Houston State University, Huntsville, Texas 77341

\begin{abstract}
Vegetation composition is often dictated by grazing intensity in semiarid savannas; recovery following drought may depend on pre drought species composition. Nests of the red harvester ant, Pogonomyrmex barbatus, affect the dynamics, composition and recovery of post drought communities due to their larger size, greater seed production and higher perennial grass richness. We hypothesized that vegetation at ant nests would survive drought and recover faster than vegetation in the surrounding grasslands, but that individual and population recovery would depend on plant species composition, which, in turn, would be influenced by grazing intensity. We assessed nest influence on density, cover, number of inflorescences and dynamics of grass and forb species. Disk margins (area encircling the ant nest) were compared with grassland locations in unreplicated heavy, light and ungrazed treatments before, immediately after and one year after a severe drought. Significantly greater aerial and basal cover of grasses was found on disk margins compared to grasslands in each treatment. Grass cover and number of inflorescences increased faster on disk margins compared to grasslands. Fastest grass growth was seen on margins in the ungrazed treatment. There was greater diversity in ungrazed treatments of grazing intolerant mid-grasses compared to the grazed treatments, suggesting that mid-grasses may persist belowground, leading to faster productivity in the ungrazed treatment. Grass densities were generally higher and increased faster in grasslands resulting in smaller grasses compared to the large, more robust grasses on disk margins. Forbs showed significantly lower abundance and cover on margins compared to grasslands. These observations suggest that red harvester ant nests may serve as drought refugia for grass survival and a seed source for recovering grass populations after drought in semiarid savannas.
\end{abstract}

\section{INTRODUCTION}

Ants are well documented as influential agents of soil change. As ecosystem engineers, they create nest patches altering resource availability for plant species. Harvester ant nest patches often increase plant diversity and performance (MacMahon et al., 2000). The genus Pogonomyrmex contains species of harvester ants that create bare soil disks approximately $1 \mathrm{~m}$ diameter by clearing all vegetation (Rissing, 1988; Whitford and DiMarco, 1995; Wagner, 1997; Gordon, 1999; MacMahon et al., 2000). Plants encircling the disk, however, tend to be larger and produce more seeds than plants in surrounding habitats (Golley and Gentry,

\footnotetext{
${ }^{1}$ Corresponding author present address: Department of Agronomy and Horticulture, 279 Plant Sciences, University of Nebraska, Lincoln 68583; Telephone: (402) 472-1953; FAX: (402) 472-7904; email: ACNIC240@aol.com
} 
1964; Wight and Nichols, 1966; Rissing, 1986; Whitford, 1988; Soule and Knapp, 1996). Vegetation composition around the disks often differs from adjacent areas: shrub and perennial forb richness is lower, whereas grass richness is higher (Rissing, 1986; Soule and Knapp, 1996; Lei, 1999). Although most studies of vegetation at the edge of disks focus on structure and composition, the disk and the plants at its margin are a unique patch type that may have a distinctive ecosystem function: to provide refugia and accelerate recovery during and following environmental stresses.

At landscape scales, vegetation structure is driven by large scale factors. Before European settlement, natural herbivory, periodic fires and weather variability were major factors in maintaining the liveoak savanna parkland of the Edwards Plateau of Texas (Smeins and Merrill, 1988; Fuhlendorf et al., 2001). With settlement the suppression of fire, demise of large, free roaming herbivores and the introduction of confined grazing by livestock transformed the structure of these parklands to woodlands (Smeins and Merrill, 1988; Fuhlendorf and Smeins, 1997). Confined, intense grazing altered the structure and composition of the grassland community to early-successional, short grasses with a low diversity of forbs and low total cover (Smeins and Merrill, 1988; Briske and Hendrickson, 1998; Fuhlendorf et al., 2001). With removal or lessening of grazing, mid-grasses and perennial forb species become most abundant and cover increases (Fuhlendorf and Smeins, 1997). Nevertheless, weather remains a strong driver in community structure. Droughts slow recovery of grazed grassland communities by reversing their composition to more earlysuccessional species and increasing bare soil (Fuhlendorf et al., 2001).

In addition to these ubiquitous large scale factors, smaller scale phenomena caused by small mammals, birds and insects can influence the composition, structure and patch dynamics of these ecosystems (Collins and Barber, 1985; Whiticker and Detling, 1988; Cloudsley-Thompson, 1996; Carson and Root, 1999). Pogonomyrmex disks and nests form unique soil patches in terms of their chemistry, texture, moisture, microbial and mycorrhizal communities (Carlson and Whitford, 1991; McGinley et al., 1994; Whitford and DiMarco, 1995; Carson and Root, 1999; Lei, 2000; Snyder et al., 2002; Boulton et al., 2003; Wagner and Jones, 2004; Wagner et al., 2004). Our preliminary study of water infiltration rates is consistent with Lei's (2000) report of higher infiltration rates at Pogonomyrmex nests compared with adjacent areas.

Individuals survive droughts because they have physiological adaptations or find refuge from the stress (Clements, 1934; Jacobsen and Kleynhans, 1993; Magoulick and Kobza, 2003; Fritz and Dodds, 2004; Shackelford, 2004). By inhabiting a refuge, a place where the negative effects of drought are lower than in the surrounding area, organisms can avoid the effects of drought (Lancaster and Belyea, 1997) and their survival rate can increase over those outside the refuge (Shackelford, 2004). Vegetation associated with nests could avoid harsh conditions of drought and tolerate historical livestock grazing compared to plants in nearby areas perhaps due to greater soil moisture. Therefore, Pogonomyrmex nests may act as drought refugia and accelerate recovery of vegetation.

The aim of this study was to assess the influence of red harvester ant (Pogonomyrmex barbatus) nests on herbaceous community composition, structure and dynamics during and immediately following a drought by comparing disk margins with adjacent grassland inside longterm (approximately $60 \mathrm{y}$ ) heavily grazed, lightly grazed and ungrazed treatments. More specifically, we hypothesized that perennial and annual grass and forb composition, density and cover would be greater at disk margins compared to grasslands during drought. We further hypothesized that there will be greater responses of plant cover, density and reproduction and higher species richness on disk margins compared to adjacent habitat 
following drought. Finally, we hypothesized that these patterns would be stronger in ungrazed compared to two grazed regimes.

\section{StUdy AREA}

The study was conducted at the Texas A\&M University Agricultural Research Station, Edwards Plateau, Texas (elevation $735 \mathrm{~m}, 31^{\circ} 18^{\prime} \mathrm{N} ; 100^{\circ} 28^{\prime} \mathrm{W}$ ). Vegetation is a mixed-grass, savanna parkland dominated by groves of liveoak (Quercus virginiana Mill), pungent oak (Q. pungens Liebm. var. vaseyana), Ashe juniper (Juniperus ashei Buchholz) and Pinchot juniper (J. pinchotii Sudw.) in a matrix of mid- and short-grass species (Kuchler, 1975; Smeins and Merrill, 1988; Hatch et al., 1990). Grassland at the study site is dominated by the grasses sideoats grama (Bouteloua curtipendula (Michx.) Torr.), Texas wintergrass (Stipa leucotricha Trin. \& Rupr.), curly mesquite (Hilaria belangeri (Stead.) Nash) and red grama (Bouteloua trifida Thurb.). The grassland community is noted for its heterogeneity due to the shallow rocky limestone derived soils (Fuhlendorf and Smeins, 1998). The study area had been partitioned into three treatments that were heavily grazed (19 animals $\mathrm{km}^{-2}$ ), lightly grazed ( six animals $\mathrm{km}^{-2}$ ) or ungrazed by livestock from 1948 until 1969 (Station Records). Vegetation in the ungrazed treatment consists primarily of the late successional grasses Texas wintergrass, sideoats grama and slim tridens (Tridens mutica (Torr.) Nash) with a high diversity of perennial forbs and approximately $50 \%$ shrub cover. Common grasses in the lightly grazed treatment include sideoats grama, three awn (Aristida spp. L.) and curly mesquite, an early successional species, with nearly $20 \%$ cover of shrubs. In contrast, early successional grasses, annual forbs and $40 \%$ shrub cover occurs in the heavily grazed treatment. Since 1969 the heavily grazed treatment was reduced to light levels of grazing; nevertheless, vegetation composition still consists largely of early successional species. The ungrazed treatment has been continually protected from domestic herbivory since 1948 .

The climate is continental and semiarid with a bimodal distribution (peaks in May and Sep.) of growing season rainfall. Average annual precipitation (1919-2003) is $57.5 \mathrm{~cm}$, but variability between years is great with a range of $35.7 \mathrm{~cm}$ and standard deviation of $5.1 \mathrm{~cm}$ (Station Records). Temperatures average $30 \mathrm{C}$ in Jul. and $9 \mathrm{C}$ in Jan. (Station Records). Station records (within $3 \mathrm{~km}$ of study sites) showed that a severe growing season drought began in 1997 (Shackelford, 2004). For the next five growing seasons the Palmer Drought Severity Index showed a deficit of $<-1.0$ PDSI. Repeated growing season droughts that continued until Jul. 2002 resulted in high mortality of warm season $\left(\mathrm{C}_{4}\right)$ grasses. Above normal precipitation began in Jul. 2002 and continued in 2003.

\section{Methods}

To examine the impact of red harvester ant nests on the herbaceous community, all nests were mapped and marked in one pasture each of heavily grazed (32 ha), lightly grazed (32 ha) or ungrazed (11 ha) grassland. Fifteen nests were selected randomly in each pasture, making a total of 45 nests. Data were collected during three sampling periods: Jun. 2002, the last month of drought; Oct. 2002, 3 mo after a return to normal rainfall; and Aug. 2003, 1 y later.

In order to determine whether vegetation surrounding ant disks differed from vegetation in grasslands, all plants were recorded using a circular quadrat with concentric rings $15 \mathrm{~cm}$ wide, starting from the nest entrance and extending to $105 \mathrm{~cm}$, well beyond the cleared disk (Fig. 1). Preliminary analysis indicated that most of the $1.02 \mathrm{~m}(0.20 \mathrm{SD})$ diameter disk is devoid of vegetation and the last four rings have considerable grass basal cover. Moreover, the furthest ring from the disk has lower basal cover compared to rings next to the disk 


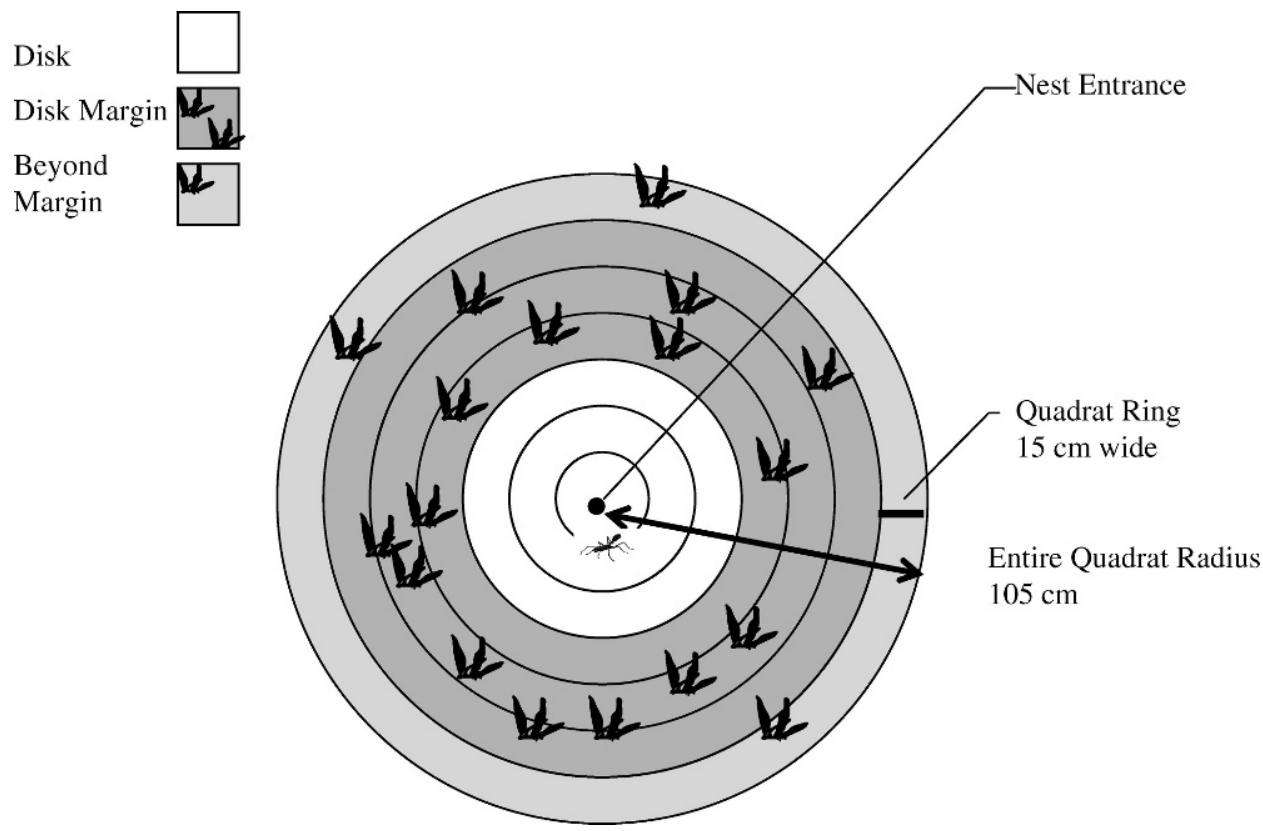

Fig. 1.-Diagram of the circular sampling quadrat with rings superimposed on a Pogonomyrmex barbatus disk and a disk margin

(Fig. 1), therefore, only rings with high basal cover were included in further analyses. They were defined as the disk margin location.

Disk margins in the heavily grazed treatment consisted of two concentric rings $(30 \mathrm{~cm}$ wide) and disk margins in lightly grazed and ungrazed treatments consisted of three concentric rings $(45 \mathrm{~cm}$ wide). Data within these two or three concentric rings were pooled for analyses. Mean area of the disk margin was $2.3 \mathrm{~m}^{2}$ in lightly and ungrazed treatments, and $1.4 \mathrm{~m}^{2}$ in the heavily grazed treatment. Vegetation was also sampled $3.5 \mathrm{~m}$ from the center of the disk in two random cardinal directions with a $0.50 \times 0.50 \mathrm{~m}$ quadrat; total area of the combined quadrats was $1.0 \mathrm{~m}^{2}$. Data from the two quadrats were analyzed as the grassland location. Although sampling with quadrats of uniform size and shape reduces error (Krebs, 1999), we employed circular and square quadrats to expedite sampling. By using the smaller quadrat in the grassland locations, we may have overestimated densities during drought when individuals were rare, but sampling appeared to be representative of the vegetation. Due to the differences in shape and area, all data were standardized to $\mathrm{m}^{-2}$. Vegetation was not sampled under woody plants or in rock outcrops to avoid marked variation from the herbaceous community at ant nests.

Data collected for each grass species were number $\mathrm{m}^{-2}$, number of inflorescences plant $^{-1}$, percent basal and percent aerial cover. The data collected for each perennial and annual forb species were number $\mathrm{m}^{-2}$ and percent aerial cover. Estimate of aerial cover of live vegetation was measured in each quadrat at the top of the plants by visually estimating coverage of the foliage vertically projected upon the ground (Bonham, 1989). It was expressed as percentage of the ground surfaces covered by foliage in each quadrat (Whittaker, 1965; Bonham, 1989). Aerial cover varies considerably with degree of grazing 
TABLE 1.-Repeated measures ANOVA for effects of heavily grazed, lightly grazed and ungrazed treatments, during (Jun. 2002) and after (Oct. 2002 and Aug. 2003) drought, at red harvester ant disk margin and grassland locations on perennial grass and perennial and annual forb variables at Sonora Research Station, Texas. $\mathrm{n}=15$ nests

\begin{tabular}{|c|c|c|c|c|c|c|c|c|c|}
\hline \multirow{2}{*}{\multicolumn{2}{|c|}{ Main effect }} & \multicolumn{2}{|c|}{ Density } & \multicolumn{2}{|c|}{ Aerial cover } & \multicolumn{2}{|c|}{ Basal cover } & \multicolumn{2}{|c|}{$\begin{array}{c}\text { Number of } \\
\text { inflorescences }\end{array}$} \\
\hline & & $\mathrm{F}$ & $\mathrm{P}$ & $\mathrm{F}$ & $\mathrm{P}$ & $\mathrm{F}$ & $\mathrm{P}$ & F & $\mathrm{P}$ \\
\hline \multirow[t]{4}{*}{ Grasses } & Grazing & 12.02 & $<0.001$ & 15.98 & $<0.001$ & 21.65 & $<0.001$ & 19.49 & $<0.001$ \\
\hline & Location & 7.72 & 0.007 & 40.04 & $<0.001$ & 26.21 & $<0.001$ & 3.85 & 0.050 \\
\hline & Date & 103.50 & $<0.001$ & 323.12 & $<0.001$ & 399.68 & $<0.001$ & 11.77 & 0.001 \\
\hline & $\begin{array}{c}\text { Location } \times \\
\text { date }\end{array}$ & 5.01 & 0.012 & 24.03 & $<0.001$ & 19.43 & $<0.001$ & 3.21 & 0.080 \\
\hline \multicolumn{10}{|l|}{ Perennial } \\
\hline \multirow[t]{4}{*}{ forbs } & Grazing & 5.51 & 0.005 & 7.03 & 0.002 & $-\mathrm{b}$ & $-\mathrm{b}$ & $-\mathrm{a}$ & $-\mathrm{a}$ \\
\hline & Location & 57.37 & $<0.001$ & 41.18 & $<0.001$ & & & & \\
\hline & Date & 28.03 & $<0.001$ & 67.23 & $<0.001$ & & & & \\
\hline & $\begin{array}{c}\text { Location } \times \\
\text { date }\end{array}$ & 25.41 & $<0.001$ & 39.74 & $<0.001$ & & & & \\
\hline \multirow[t]{4}{*}{ Annual forbs } & Grazing & 7.34 & 0.001 & 13.36 & $<0.001$ & $-b$ & $-b$ & $-\mathrm{a}$ & - $\mathrm{a}$ \\
\hline & Location & 80.21 & $<0.001$ & 11.37 & 0.001 & & & & \\
\hline & Date & 190.30 & $<0.001$ & 171.64 & $<0.001$ & & & & \\
\hline & $\begin{array}{c}\text { Location } \times \\
\text { date }\end{array}$ & 66.87 & $<0.001$ & 7.17 & 0.004 & & & & \\
\hline
\end{tabular}

$\mathrm{a}=$ Data not collected

$\mathrm{b}=$ Not applicable

use and seasonal weather conditions in perennial grasses, thus basal cover (the area of ground covered by the basal part of the grass) is a more meaningful measure of the size of the grass clump whereas aerial cover measures tillers (Bonham, 1989). Basal cover of each species was estimated visually $2 \mathrm{~cm}$ above the ground surface. At each nest, plant cover gathered from the two grassland quadrats was summed. Species of grasses sampled were grouped into grazing tolerant (early successional species including red grama, three awn species and curly mesquite) or grazing intolerant (mid to late successional species including sideoats grama, Texas wintergrass, slim tridens and vine mesquite (Panicum obtusum H. B. K.)) (Smeins and Merrill, 1988; Fuhlendorf and Smeins, 1997).

To compare vegetation on the disk margin relative to grassland, a repeated measures oneway treatment in a randomized complete block design ANOVA was conducted (Zar, 1996). Data did not meet the assumption of sphericity using Bartlett's or Mauchly's tests, therefore a Greenhouse-Geiser correction was used for degrees of freedom. Grazing treatment was not replicated, therefore, it was analyzed as a block effect. All analyses were performed using SPSS (SPSS, 2001).

\section{RESULTS}

Vegetation in the semiarid savanna of the study site varied as a function of location, grazing treatment and sampling period, and most of the repeated measures interactions were significant (Table 1). While in general, grass variables increased after the drought, disk margins increased faster compared to grassland locations as indicated by the significant sampling period interactions in aerial and basal cover (Fig. 2). 


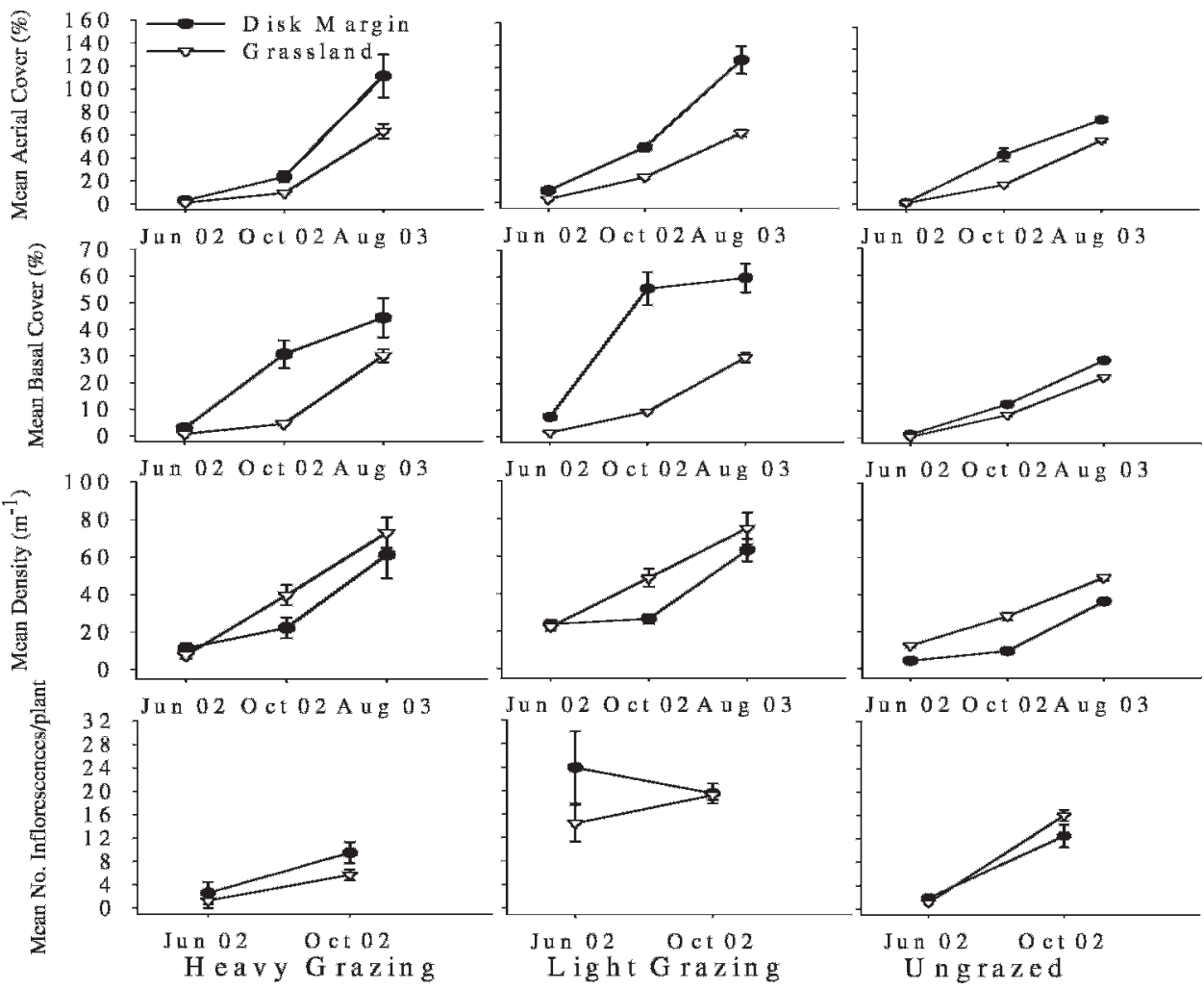

Fig. 2.-Interactions of perennial grass variables in heavily grazed, lightly grazed and ungrazed treatments, at red harvester ant disk margins and grassland locations, during (Jun. 2002) and after (Oct. 2002 and Aug. 2003) drought at Sonora Research Station, Texas. n $=15$ nests. Numbers of inflorescences plant $^{-1}$ were not recorded in Aug. 2003. Data are means (95\% cI)

Aerial and basal grass cover was higher on the disk margin compared to the grassland during each sampling period (Fig. 2). Aerial and basal cover increased faster on disk margins between Jun. and Oct. 2002 and aerial cover only between Oct. 2002 and Aug. 2003, except during the later period in the ungrazed treatment when cover increased similarly (Fig. 2). The number of inflorescences per plant was significantly higher on disk margins compared to grassland; however there were no sampling period interactions (Table 1). The ungrazed treatment had higher numbers of inflorescences per plant in grassland in Oct. 2002 (Fig. 2).

In contrast, grassland locations generally had significantly higher densities of grasses compared with disk margins (Table 1), resulting in a larger quantity of smaller plants in the former and fewer larger plants in the latter. During drought, however, grass density on the disk margin and grassland varied by grazing treatment (Fig. 2). During recovery, density was always higher in grassland and it increased faster in this location only between Jun. and Oct. 2002.

The proportion of grazing tolerant, early successional species was highest in the heavily grazed treatment and lowest in the ungrazed (Fig. 3). In contrast, the ungrazed treatment was dominated by grazing intolerant, mid to late successional species. Early successional species 

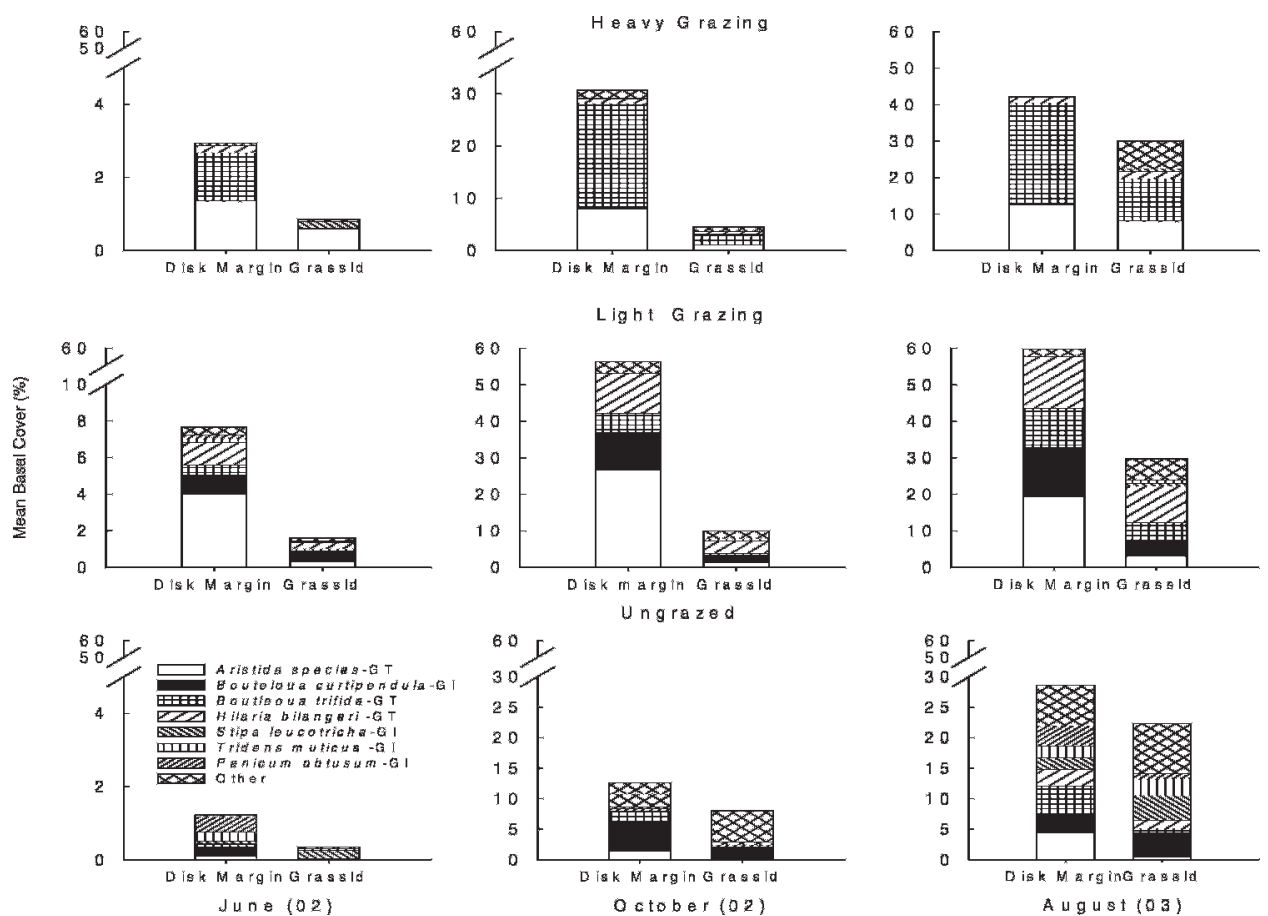

FIG. 3.-Mean basal cover of grass species in heavily grazed, lightly grazed and ungrazed treatments, at red harvester ant disk margin and grassland locations, during (Jun. 2002) and after (Oct. 2002 and Aug. 2003) drought at Sonora Research Station, Texas. GT = grazing tolerant, early-successional species and GI = grazing intolerant, mid-to late-successional species. NOTE: break point in each graph shows where the scale varies

typically had fewer inflorescences per plant compared to mid to late successional species. Grazed treatments had significantly greater aerial and basal cover and density compared to ungrazed treatments (Fig. 2). The number of inflorescences plant ${ }^{-1}$ was significantly higher in the grazed treatment only during the drought because few mid-grasses were above ground.

By comparing mean basal cover among recovery periods and initial mean basal cover during the final month of drought, ratios could be used to compare the relative rate of recovery among the three grazing treatments. Recovery was greatest in ungrazed areas with an increase in Oct. 2002 of 1:10 and in Aug. 2003 of 1:32. Lower rates occurred inside lightly grazed areas during corresponding dates (Oct. 2002 1:6; Aug. 2003 1:10), and least inside heavy grazing areas (Oct. 2002 1:5), except in Aug. 2003 where heavy grazing yielded higher recovery rates than light grazing (1:20). Red grama and sideoats grama showed the greatest response in all three grazing treatments (Fig. 3).

Cover and density of annual forbs were highly affected by seasonal rainfall (Fig. 4). Cool season annuals made up the majority of plants during the drought because there was sufficient winter rainfall for their emergence. Large numbers of annual forb seedlings emerged after the drought, blanketing the study area. Generally, in all sampling periods, annual and perennial forbs had significantly greater density and cover in the grasslands relative to the disk margins (Table 1). Perennial forb cover and density recovered faster in grassland (Fig. 4), as suggested by the significant repeated measures interactions (Table 1). 


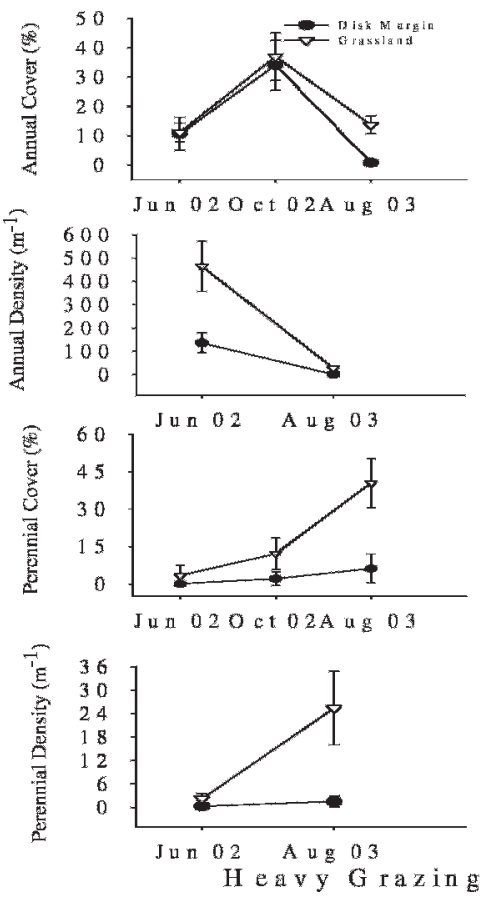

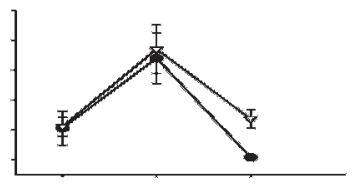

Jun 020 et $02 \mathrm{~A}$ ofg 03
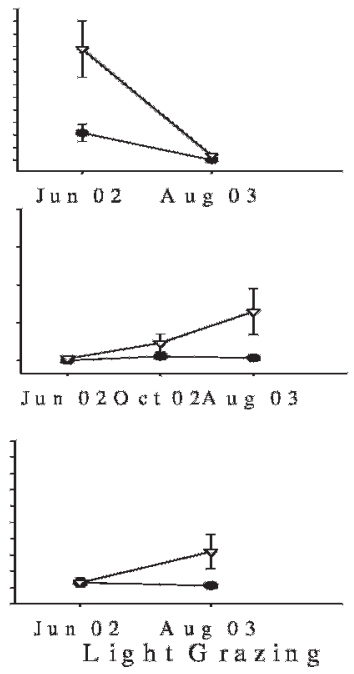

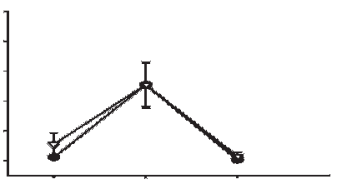

I u 020 ct $02 \mathrm{~A} \mathrm{ug} 03$

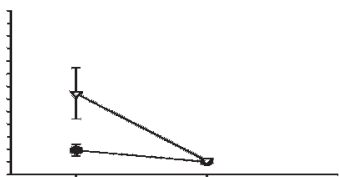

Jun $02 \quad$ Oet 02

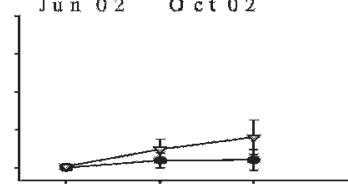

Jun 020 ct $02 \mathrm{Aug} 03$

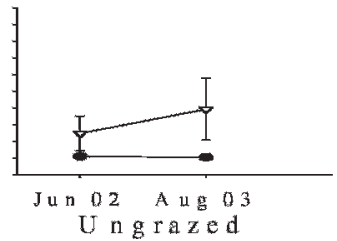

FIG. 4.-Means of annual and perennial forb variables in heavily grazed, lightly grazed and ungrazed treatments, at red harvester ant disk margins and grassland locations, during (Jun. 2002) and after (Oct. 2002 and Aug. 2003) drought at Sonora Research Station, Texas. n = 15 nests. Density data were not collected in Oct. because thousands of seedlings appeared. Data are means (95\% CI)

The grazed treatments had more annual and perennial forb cover and density than ungrazed treatments (Fig. 4); however, during the drought perennial forb density was highest in the ungrazed treatment.

\section{Discussion}

These results describe, for the first time, plant community composition, structure and dynamics at red harvester ant nests in a semiarid savanna region. Our results agree with previous studies that found that vegetation structure and composition often differ between harvester ant disk margins and surrounding vegetation (Costello, 1944; Whitford, 1988; Carlson and Whitford, 1991; Brown and Human, 1997; Wilby et al., 2001; Peters et al., 2005). Perennial grasses had greater basal and aerial cover on disk margins compared to grasslands and perennial forb cover was lower on disk margins (Table 1).

This study suggests an important functional role for harvester ant nests, as drought refugia for grasses. Red harvester ant disk margins appear to act as drought refugia because grasses flourish better on disk margins during drought. This could be due to higher moisture in nest soils compared to surrounding locations, an occurrence known for harvester ant nests (Carlson and Whitford, 1991; Whitford and DiMarco, 1995). Only one documented instance of a potential plant refugium maintained by animals is known: that of the termite created soils around Mulga (Acacia aneura) logs (Tongway et al., 1989). 
Grass cover recovered more rapidly on red harvester ant disk margins, and the most rapid recovery was found on margins in ungrazed areas. This may be partly attributable to the greater survivability of grasses on disk margins during the drought, so that they are better able to respond to the return of normal rainfall. The present study suggests that individual plant recovery is contingent on species identity because ungrazed treatments consist of larger, late successional species with deep root systems compared to heavily grazed treatments that support smaller early successional species often with shallow roots. During drought, larger species maintain themselves by dying back aboveground, reducing reproductive inflorescences and sustaining their root systems. During early recovery in the ungrazed treatment, late successional species resprouted from their large surviving basal crown, as illustrated by the greater recovery ratios in ungrazed treatments. This pattern was exhibited in the grazed treatments, but only on disk margins, leading to the hypothesis that all grasses may retain larger root systems at disk margins. As noted above, soil depth is shallow and variable at the study site, therefore, ants may locate nests in deeper soils or, at least, in soil filled cracks in the limestone because they need space for their nests, thus they might choose deeper soils that indirectly lead to greater grass production.

Another explanation for the differences in grass growth between locations may be better resources on nests. Reproductive allocation measured as number of inflorescences per individual was greater on disk margins compared to grasslands in the heavily grazed treatment, but not in the lightly grazed and ungrazed treatments. In the heavily grazed treatment, the difference between resources for reproduction in surrounding habitats compared to disk margins may be greater than in pastures with less grazing. During drought, a similar pattern was observed for grass density. Resources at nests in the ungrazed treatment may be only slightly better than grassland locations because aerial and basal cover increased at similar rates between Oct. 2002 and Aug. 2003.

Grass density increased more rapidly in grassland between Jun. and Oct. 2002. This increase is dependent upon abundance of post-dispersed seeds during the drought and, because the number of inflorescences was generally higher at disk margins, these individuals may constitute an important seed source. Organisms that survive in refugia typically recolonize surrounding habitats when the drought is over (Ludwig and Tongway, 1995; Fritz and Dodds, 2004). Lower densities on disk margins could be due to increased competition for resources between seedlings and the bigger, more productive adults on the margin. However, lower densities at disk margins could be due to higher seed predation by workers on the nests compared to grassland locations (Brown and Human, 1997; Peters et al., 2005).

In contrast, annual and perennial forb cover and density was significantly lower on disk margins relative to surrounding grasslands in all grazing treatments. These findings are supported by other studies on harvester ant disks (Nowak et al., 1990; Whitford and DiMarco, 1995; Soule and Knapp, 1996; Lei, 1999). These results suggest that ant nests are similar in their ability to create patches with unique plant communities in many habitat types throughout the ranges of this group of harvester ants. Their patch effects are tempered by large scale disturbance regimes.

During recovery between Jun. and Oct. 2002, annual forb densities in all quadrats were similar because their seedlings blanketed nearly $75 \%$ of the ground surface despite location or grazing treatment. Perhaps pulses of rainfall that cause synchronous germination of common annual forbs may account for these observations. Seed harvesting by ants may not reduce the number of seeds available for germination. During recovery between Oct. 2002 and Aug. 2003, perennial forb cover was significantly higher in grasslands compared to at the disk margins. This difference was smallest in the ungrazed treatment, probably due to 
the overall better conditions of the treatment. Ant disks may not improve resources for forbs.

The present study found grass species composition unvarying between the margin and grassland (Fig. 3). Instead, grass composition on the margin reflects past grazing history. The suite of grass species available for recruitment following a drought is determined by this large scale disturbance regime. Research using other ant genera, as well as harvester ants, found that large scale disturbances such as fire, flooding, agricultural practices and heavy grazing outweigh disk or nest effects in terms of species composition (Wight and Nichols, 1966; Carlson and Whitford, 1991; Lewis et al., 1991; Folgarait et al., 2002).

Longterm grazing drives community structure at the study site so that differences are generally attributed to grazing levels and amount of shrub cover and this may be the most likely cause of differences among plant density and cover in the grazing treatments. Although grasses in the ungrazed treatment recovered faster than in either of the grazing treatments, absolute means of basal cover remained lower than in the grazed treatments. In semiarid savannas, juniper cover is known to reduce biomass and basal cover of herbaceous vegetation under shrubs (Armentrout and Peiper, 1988; Fuhlendorf and Smeins, 1997; Yager and Smeins, 1999) up to $7 \mathrm{~m}$ away from canopy edges (Dye II et al., 1995; Breshears $e t$ al., 1997a, b). Nearly all nests and the grassland locations situated away from them were found within $5 \mathrm{~m}$ of juniper cover in the ungrazed treatment compared to the grazed treatments, where few nests were found near shrub canopies. Dye II et al. (1995) found that herbaceous biomass was significantly reduced away from juniper canopies in shallow soils where both shrub and grass roots may be competing for resources. Therefore, the juniper cover found near disk margins and grassland locations may restrain grass basal cover. The ungrazed treatment supports few, but large, grasses due to the greater diversity of mid-size, late successional species. During drought its composition leads to a greater aboveground dieback with perhaps greater belowground persistence thus leading to faster individual recovery in this treatment when the drought ends.

During droughts, grasses can persist and express greater growth on harvester ant disk margins than in surrounding herbaceous habitats. As a result, harvester ant nests act as refugia during droughts and accelerate individual grass recovery following drought. As areas of high grass survivability and reproduction during drought, they may act as foci for grass seed dispersal into surrounding habitats. The spatial pattern of harvester ant nests may influence the pattern of seed dispersal and seedling establishment and the density of nests may determine their degree of influence. These observations suggest that red harvester ant nests may serve as reservoirs of plant survival and a seed source for recovering vegetation after drought.

Acknowledgments. - We thank Charles A. Taylor, Jr. for technical support and A. Christina Longbrake for statistical advise. This work was generously supported, financially and logistically, by Texas A\&M University Graduate Merit Fellowship, a Tom Slick Senior Graduate Fellowship, and the Texas A\&M University Experiment Station at Sonora. The authors thank Zoe Groner for careful review of an earlier version of the manuscript. Five anonymous referees made helpful suggestions on earlier drafts.

\section{Literature Cited}

Armentrout, S. M. and R. D. Peiper. 1988. Plant distribution surrounding Rocky Mountain pinyon pine and one seed juniper in south-central New Mexico. J. Range Mgt., 41:139-143.

Bonham, D. 1989. Measurements for terrestrial vegetation. John Wiley and Sons, Inc., New York. 338 p. Boulton, A. M., B. A. JAffee And K. M. Scow. 2003. Effects of a common harvester ant (Messor andrei) on richness and abundance of soil biota. Appl. Soil. Ecol., 23:257-265. 
Breshears, D., O. Myers, S. Johnson, C. Meyer and S. Martens. 1997a. Differential use of spatially heterogeneous soil moisture by two semiarid woody species: Pinus edulis and Juniperus monosperma. J. Ecol., 85:289-299.

— P. Rich, F. Barnes and K. Campbell. 1997b. Overstory-imposed heterogeneity in solar radiation and soil moisture in a semiarid woodland. Ecol. Appl., 7:1201-1215.

BRISKE, D. D. AND J. R. Hendrickson. 1998. Does selective defoliation mediate competitive interactions in a semiarid savanna? A demographic evaluation. J. Veg. Sci., 9:611-622.

Brown, M. J. F. And K. G. Human. 1997. Effects of harvester ants on plant species distribution and abundance in a serpentine grassland. Oecologia, 112:237-243.

Carlson, S. R. and W. G. Whitford. 1991. Ant mound influence on vegetation and soils in a semiarid mountain ecosystem. Am. Midl. Nat., 126:125-139.

Carson, W. P. and R. B. Roоt. 1999. Top-down effects of insect herbivores during early succession: influence of biomass and plant dominance. Oecologia, 121:260-272.

Clements, F. E. 1934. The relict method of dynamic ecology. J. Ecol., 22:39-68.

Cloudsley-Thompson, J. L. 1996. Biotic interactions in arid lands. Springer-Verlag, Berlin. 208 p.

Collins, S. L. AND S. C. Barber. 1985. Effects of disturbance on diversity in mixed-grass prairie. Vegetatio, 64:87-90.

Costello, D. F. 1944. Natural revegetation of abandoned plowed land in the mixed prairie association of northeastern Colorado. Ecology, 25:312-326.

Dye, II, K., D. Ueckert and S. Whisenant. 1995. Redberry juniper-herbaceous understory interactions. J. Range Mgt., 48:100-107.

Folgarait, P. J., S. Perelman, N. Gorosito, R. Pizzio and J. Fernandez. 2002. Effects of Camponotus punctulatus ants on plant community composition and soil properties across land-use histories. Plant Ecol., 163:1-13.

FritZ, K. M. AND W. K. Dodds. 2004. Resistance and resilience of macroinvertebrate assemblages to drying and flood in a tallgrass prairie stream system. Hydrobiologia, 527:99-112.

Fuhlendorf, S. D., D. D. BRiske And F. Smeins. 2001. Herbaceous vegetation change in variable rangeland environments: the relative contribution of grazing and climatic variability. Appl. Veg. Sci., 4:177-188.

— AND F. SMeINs. 1997. Long-term vegetation dynamics mediated by herbivores, weather and fire in a Juniperus-Quercus savanna. J. Veg. Sci., 8:819-828.

— AND - 1998. The influence of soil depth on plant species response to grazing within a semiarid savanna. Plant Ecol., 138:89-96.

Golley, F. B. ANd J. B. Gentry. 1964. Bioenergetics of the southern harvester ant, Pogonomyrmex badius. Ecology, 45:217-225.

Gordon, D. M. 1999. Ants at work: how an insect society is organized. The Free Press, New York, NY. $182 \mathrm{p}$.

Hatch, S. L., N. G. Kancheepuram and L. E. Brown. 1990. Checklist of the vascular plants of Texas. Texas Agricultural Experiment Station, College Station, TX. 158 p.

Jacobsen, N. H. G. and C. J. Kleynhans. 1993. The importance of weirs as refugia for hippopotami and crocodiles in the Limpopo River, South Africa. Water S. A., 19:301-306.

Krebs, C. J. 1999. Ecological methodology. 2nd ed. Addison Wesley Longman, Inc., New York, NY.

Kuchler, A. W. 1975. The potential natural vegetation of the conterminous United States. Special Publication No. 36. American Geographical Society, New York, NY.

Lancaster, J. and L. R. Belyea. 1997. Nested hierarchies and scale-dependence of mechanisms of flow refugium use. J. N. Am. Benthol. Soc., 16:221-238.

LEI, S. 1999. Ecological impacts of Pogonomyrmex on woody vegetation of a Larrea-Ambrosia shrubland. Great Basin Nat., 59:281-284.

2000. Ecological impacts of seed harvester ants on soil attributes in a Larrea-dominated shrubland. W. N. Am. Naturalist, 60:439-444.

Lewis, J. P., E. A. Franceschi and S. L. Stofella. 1991. Effect of ant-hills on the floristic richness of plant communities of a large depression in the Great Chaco. Rev. Biol. Trop., 39:31-39. 
Ludwig, J. A. And D. J. Tongway. 1995. Spatial organization of landscapes and its function in semi-arid woodlands, Australia. Landscape Ecol., 10:51-63.

MacMahon, J. A., J. F. Mull and T. O. CRist. 2000. Harvester ants (Pogonomyrmex spp.): their community and ecosystem influences. Annu. Rev. Ecol. Syst., 31:265-291.

Magoulick, D. D. and R. M. Kobza. 2003. The role of refugia for fishes during drought: a review and synthesis. Freshwat. Biol., 48:1186-1198.

McGinley, M. A., S. S. Dhillion and J. C. Neumann. 1994. Environmental heterogeneity and seedling establishment: ant-plant-microbe interactions. Funct. Ecol., 8:607-615.

Nowak, R. S., C. L. Nowak, T. Derocher, N. Cole and M. A. Jones. 1990. Prevalence of Oryzopsis hymenoides near harvester ant mounds: indirect facilitation by ants. Oikos, 58:190-198.

Peters, H. A., N. R. Chiariello, H. A. Mooney, S. A. Levin and A. E. Hartley. 2005. Native harvester ants threatened with widespread displacement exert localized effects on serpentine grassland plant community composition. Oikos, 109:351-359.

RIssing, S. W. 1986. Indirect effects of granivory by harvester ants: plant species composition and reproductive increase near ant nests. Oecologia, 68:231-234.

1988. Harvester ants and shrubs in the Mojave Desert. Ecology, 69:809-813.

SHACKelford, C. S. 2004. Perennial grass community response to severe drought, topo-edaphic variation, and long-term herbivory on the Edwards Plateau of Texas. Page 97. Rangeland Ecology and Management. Texas A\&M University, College Station, TX.

Smeins, F. AND L. B. Merrill. 1988. Long-term change in a semi-arid grassland, p. 144. In: B. B. Amos and F. R. Gehlbach (eds.). Edwards Plateau Vegetation. Baylor University Press, Waco, TX.

SNyder, S. R., T. O. CRist And C. F. Friese. 2002. Variability in soil chemistry and arbuscular mycorrhizal fungi in harvester ant nests: the influence of topography, grazing and region. Biol. Fer. Soils, 35:406-413.

Soule, P. T. ANd P. A. Knapp. 1996. The influence of vegetation removal by western harvester ants (Pogonomyrmex owyheehi) in a relict area of sagebrush-steppe in Central Oregon. Am. Midl. Nat., 136:336-345.

SPSS. 2001. SPSS for Windows Statistical Program. SPSS Inc., Chicago, Illinois.

Tongway, D. J., J. A. Ludwig and W. G. Whitford. 1989. Mulga log mounds: fertile patches in the semiarid woodlands of eastern Australia. Aust. J. Ecol., 14:263-268.

Wagner, D. 1997. Harvester ant nests, soil biota and soil chemistry. Oecologia, 112:232-236.

And J. B. Jones. 2004. The contribution of harvester ant nests, Pogonomyrmex rugosus to soil nutrient stocks and microbial biomass in the Mojave Desert. Environ. Entomol., 33:599-607.

_ AND D. M. GoRDOn. 2004. Development of harvester ant colonies alters soil chemistry. Soil Biol. Biochem., 36:797-804.

Whitford, W. G. 1988. Effects of harvester ant (Pogonomyrmex rugosus) nests on soils and a spring annual, Erodium texanum. Southwest. Nat., 33:482-485.

AND R. Dimarco. 1995. Variability in soils and vegetation associated with harvester ant (Pogonomyrmex rugosus) nests on a Chihuahuan Desert watershed. Biol. Fer. Soils, 20:169-173.

Whiticker, A. AND J. K. Detling. 1988. Ecological consequences of prairie dog disturbances. Bioscience, 38:778-785.

Whittaker, R. H. 1965. Dominance and diversity in land plant communities. Science, 147:250-260.

Wight, J. R. AND J. T. Nichols. 1966. Effects of harvester ants on production of a saltbush community. J. Range Mgt., 19:69-71.

Wilby, A., M. ShachaK and B. Boeken. 2001. Integration of ecosystem engineering and trophic effects of herbivores. Oikos, 92:436-444.

Yager, L. Y. And F. Smeins. 1999. Ashe juniper (Juniperus ashei: Cupressaceae) canopy and litter effects on understory vegetation in a juniper-oak savanna. Southwest. Nat., 44:6-16.

ZaR, J. H. 1996. Biostatistical analysis. Prentice Hall, Upper Saddle River. 718 p. 